\title{
粉鑛處理の研究に就て
}

\section{（大正十四年十日十八日 日本鐵鋼協會第十週年紀念大算蓝演）}

\section{製鐵所技師工學士 平川 良彥}

粉鈸處理と云ふ問題は理論としては梂めて簡單でありますが實際の作罪上には電々の困難を伴ふの で何れも獨特の方法を考察して特許を有して居るのであります。地方的狀沉によりまして種ミの方法 が行はれて居ますけれどる現今最も普通に行はる」方法は燒結法でありまして鍋焙燒、グレンダル、ド

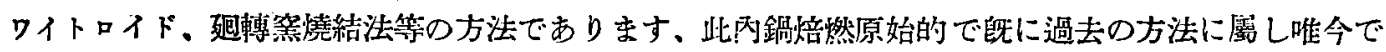
は鍋焙燒の變形なるグレンダル、ドワイトロイドの兩方法と趋轉案燒絬法 (Agglomeration process) と

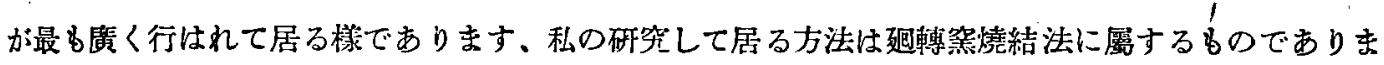

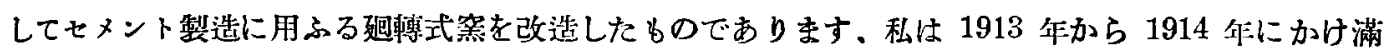
11 ヶ月間獨逸の南部即ち彼の有名なる Essen と Duisburg の中間にあります鐵の都 Oberhausen の

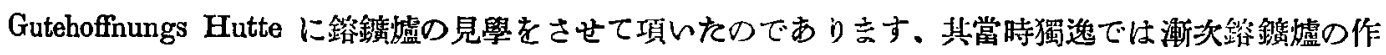

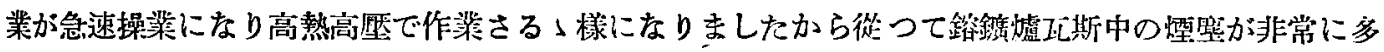
く而も鐵分に富んだものが出來ますので其の利用法として考察研究されたのが此秱轉突烧結法の起り

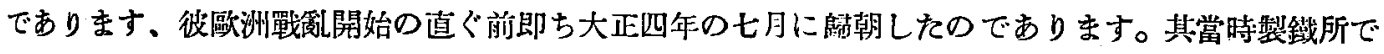

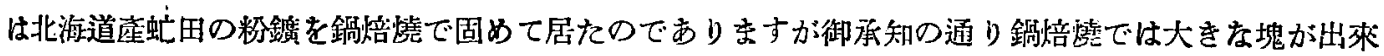

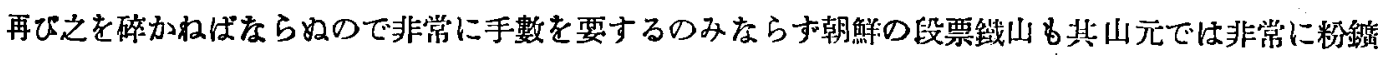

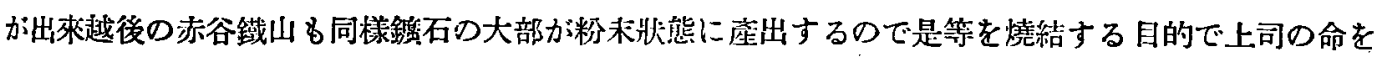
受け大正五年の末に設計したのであります。何しろ其當時獨逻でも末だ研究時代の事で作箐を見る事 でさへ心良く許されなかつた樣なかけでありますから設計に關する何等の材料も持つて歸万事は出來 なかつたのであります、其で踊退しましたけれど是非との事で記憶をたどり設計しましたのが次に示

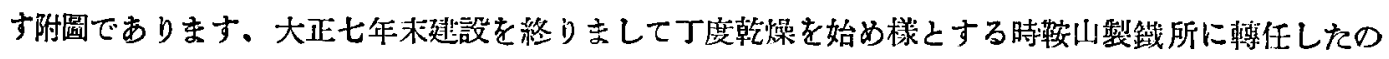
であります、其後製鐵所で試驗してたさつたそうですが機找的故障と燒絬不可能との䉆め其ま」にな つて居たのであります。大正十年末再び八幡に腒任しましたので上司の命を受け直に修繥に着手し大

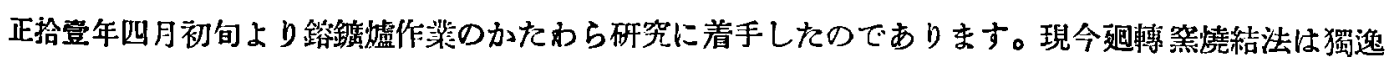
に限られて居る樣であります從つて此方法は他の國では殆んど研突されて居ない機であります、之は 地方的狀沉の爲めであるか又は作業上の關係であるか明かでありませんけれども今份濁逸殊に鐵工 ，紧の中心とも云ふべきルール地方に最も盛んに行はる」と云ふ事は誠に興味ある問題で私は非常の興 味を持つて此方法の研究を今向忹續けて居るのであります．時間の都合もありますから方として私の

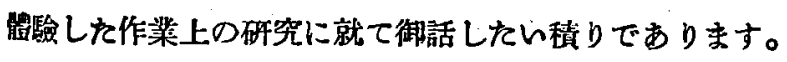




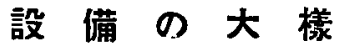

燒結に用ふる装溫は附圖に示せる通り長さ 15 米。小徑 1.52 米。大徑 2.1 米の圆筒形问轉式燒結 嘘であります、嘘體の外部は鐵板を以て園み內壁は耐火煉正を以つて較つけしてあります、ボケット

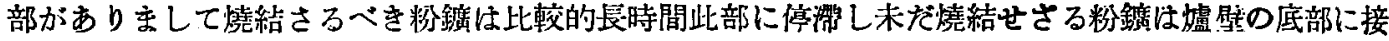

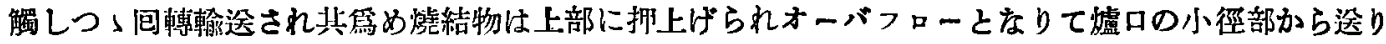

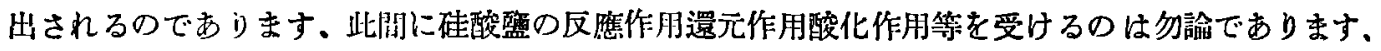

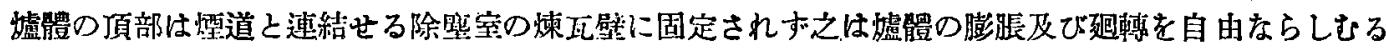

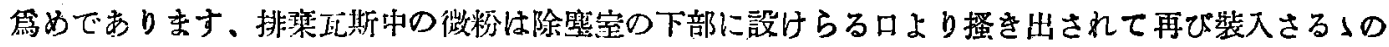

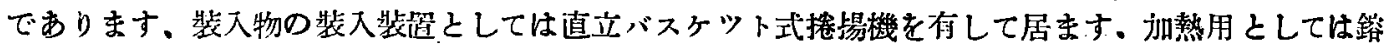

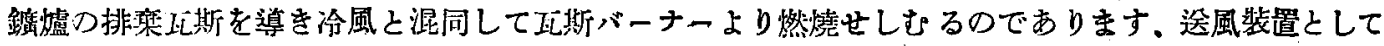

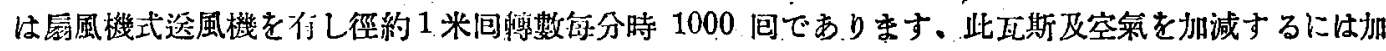

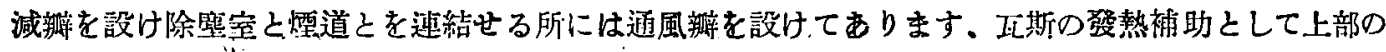
微粉炭槽より螺旋運搬機にて自動的に送炭し得る樣になつて居むす。其他の要項を舉ぐれば次の通り であります。

嘘體棟瓦總重量

同鐵皮

曥灭裝入物總重量

合計

䲣體包轉用電動機直流

包轉數氙:分時

爐體の傾科

爈體刀包轉數分分時

裴入肘電動機道流

回稪數何分時
約 25 濑

約 10 顿

約 5 濑

約 35 懒

220 ボルト 50 馬力(現在使用 30 馬力)

800

3.5 度

2.

220 ボルト 5 䭴力(現在使月 3. 馬力)

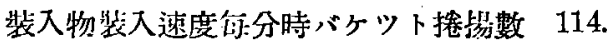

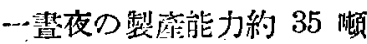

\section{機 械 的 故 障} $\cdots \cdot:$

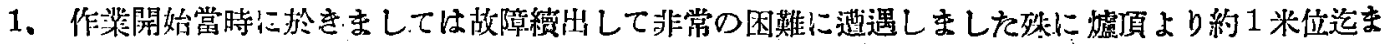

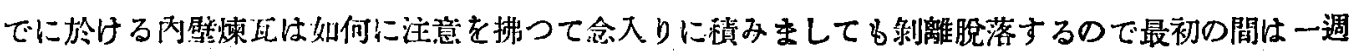

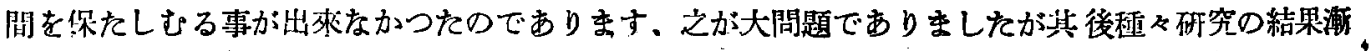
く一ヶ月位保をしむる事が出柬多少の光朋を胃とむる様になり煉瓦の脫落する時期は常に何かの故 障があつて一時作録を中止し再び開始する時に起る事が明かになりました、シャモツトは期特性と 


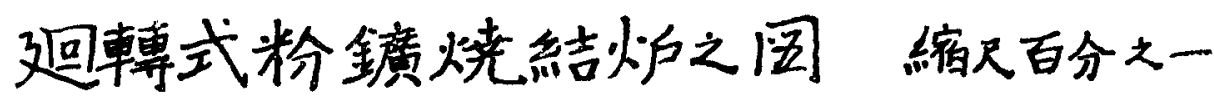

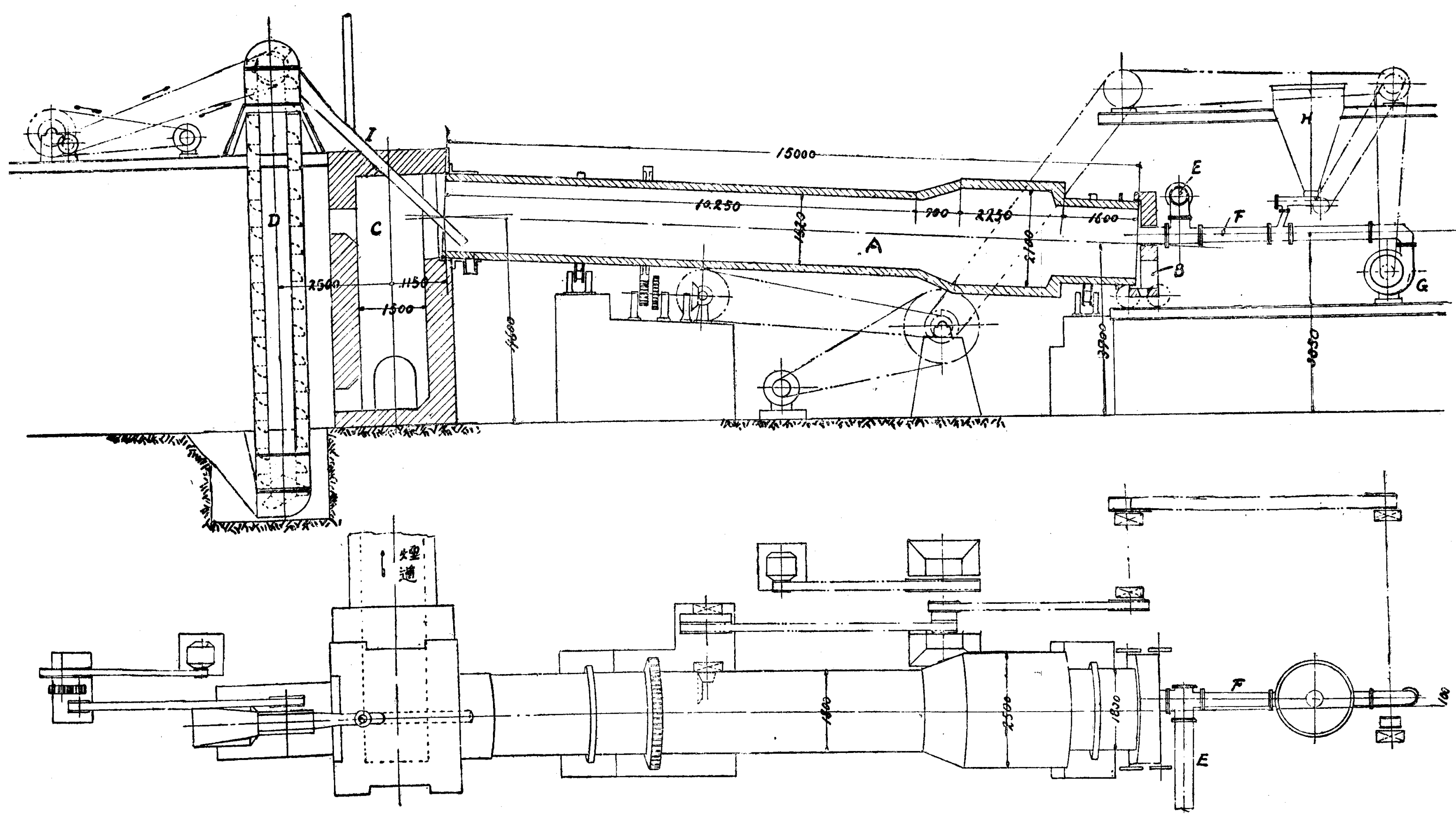


して高熱にふれ或る溫度以上になれば收縮を起しますから之がーつの原因では綮いかと云ふ洘へか らして研究部の川所博士に使用煉瓦の研究を低賴しましだ所が當所使用のシャモツト煉上は非常な

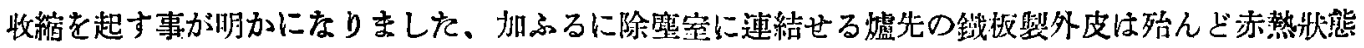

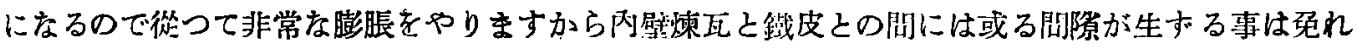
ない理けであります、然るに爐體は一圤の方向に絶へす包軩しますから其窎め煉瓦は移動し從つて

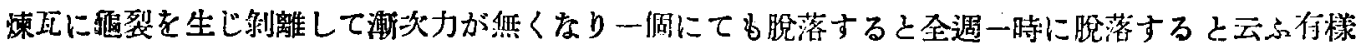

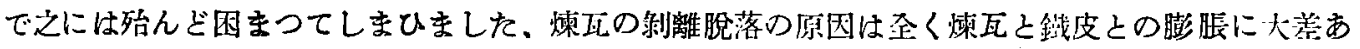
る䉆めである事が朋かになりましたので大正拾參华八月初旬虚先を改造し钱皮の膨脹を防ぐと间時

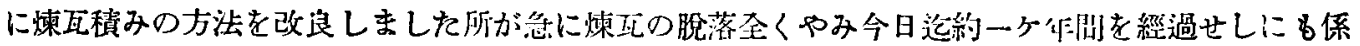

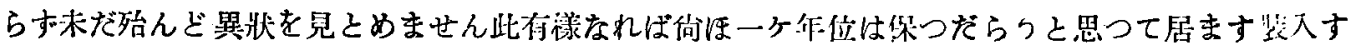

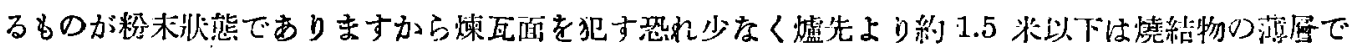

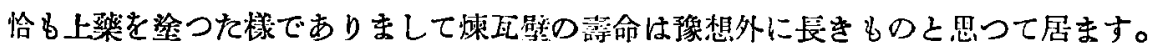

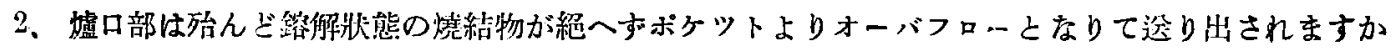

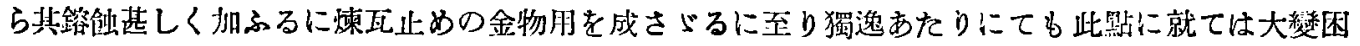

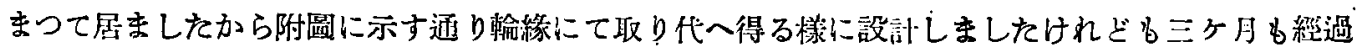

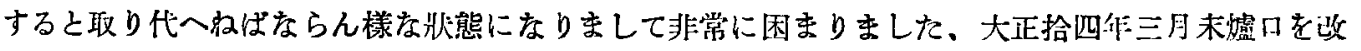

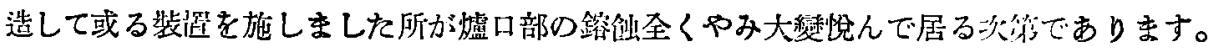

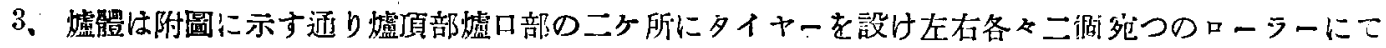

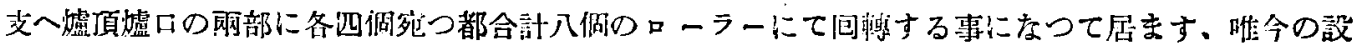

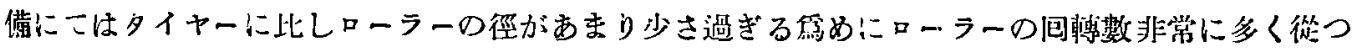

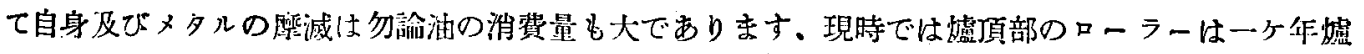

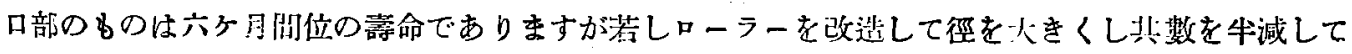

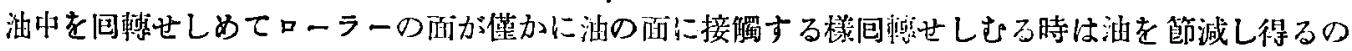
みなら殆んど牛永久的に使用す万事が出來ると思つて居ます。

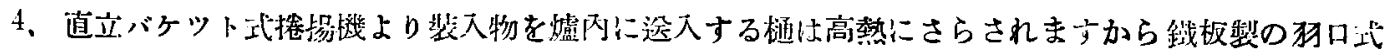

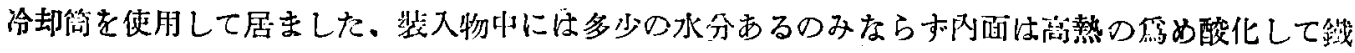

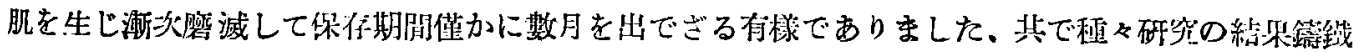

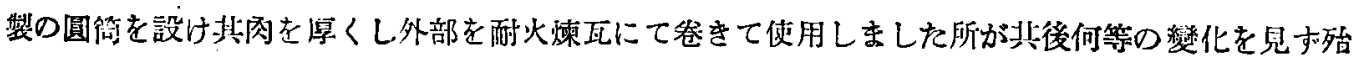
んど牛永久的に使川し得ると思つて居ます、從つて樋を取り代へる必要なく冷却水をむ節減する事 が出來る理けであります。

5、使朋する原料は微粉状のものでありますから少しにても水分を含有する場合には裝入物は装入漏

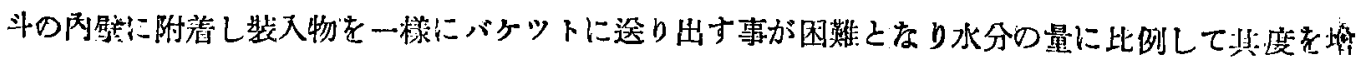


すので非常に困まつたのであり寺が種々研究の結果漏斗の下部に特種の裝管即ち圓盤を設け之が 积へ方包䡯しますから裝入物は漏斗の队臂に附着する事なくハンドルにて其量をる自由に扣堿し得 る棣になつて居ます、然し裝入物中の水分が $10 \%$ \%上になる場合には除塞室の下部に落下推皘 せる煙灰を自動的に裝入漏斗中に笑り出し繰り返へし混合装入するを普通として居ます。

以上述べました 1，2，3，4，5、等の墸點は私の體驗せる最る困まつた點でありまして趣轉害燒結 法には必捧ふわけであります。現在に於ては幸ひ殆んど理想に近き域に達して居るものと思つて居 ます。

燒 結 作 業

現今越轉突燒絬法の最も盛んに行はる」所は獨逸のルール地方でありまして主として熔鑛爐から生

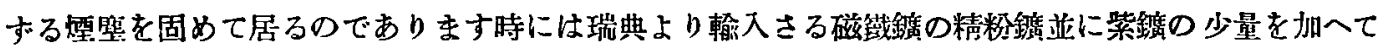

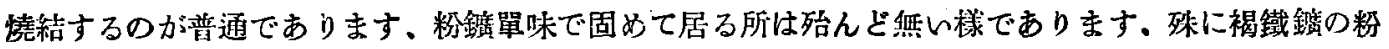

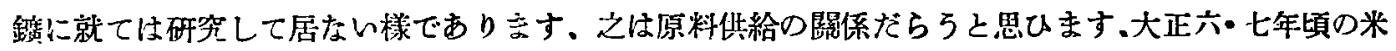

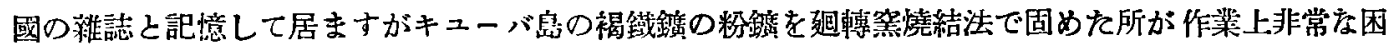

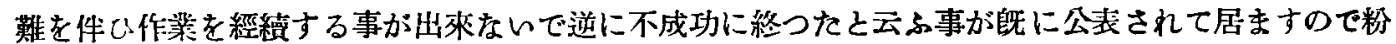

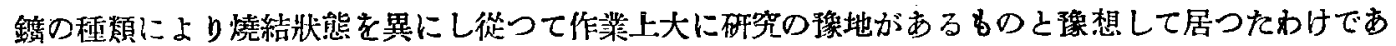
ります。私の今迄に研究しました原料は次の通りであります。

粉 鑛 分 析 韯

\begin{tabular}{|c|c|c|c|c|c|c|c|c|c|c|}
\hline & $\mathbf{F e}$ & $\mathrm{SiO}_{2}$ & $\mathrm{Al}_{2} \mathrm{O}_{3}$ & $\mathrm{MnO}$ & $\mathrm{Cu}_{4} \mathrm{O}$ & $\mathrm{MgO}$ & $\mathbf{s}$ & $\mathbf{P}$ & $\mathbf{C u}$ & $\mathrm{TiO}_{2}$ \\
\hline 㚤田褐鐵制锰 & 53.88 & 10.66 & 4.38 & 0.34 & 2.09 & 0.27 & 0.788 & 0.098 & 0.001 & - \\
\hline 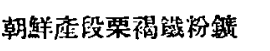 & 55.08 & 7.29 & 0.18 & 2.81 & 0.11 & 0.22 & 0.03 & 0.04 & 0.01 & - \\
\hline 行狀西 & 56.86 & 11.07 & 0.08 & 0.13 & 0.67 & 0.17 & 2.30 & 0.01 & 0.22 & \\
\hline 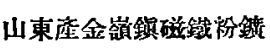 & 55.70 & 8.46 & 0.94 & 0.21 & 6.07 & 2.82 & 0.03 & 0.04 & 0.01 & - \\
\hline 森縣久意砂鐵 & 51.20 & 6.38 & 1.88 & 0.42 & 1.26 & 3.85 & 0.025 & 0.01 & 0.057 & \\
\hline
\end{tabular}

配 合 溂 分 析 表

\begin{tabular}{|c|c|c|c|c|c|c|c|c|c|c|c|c|c|}
\hline & $\mathrm{F}_{\theta} \mathrm{O}$ & $\mathrm{Fe}_{2} \mathrm{O}_{3}$ & $\mathrm{SiO}_{2}$ & $\mathrm{Al}_{2} \mathrm{O}_{3}$ & $\mathrm{Ca}$ ? & $\mathrm{MgO}$ & $\mathrm{MnO}$ & $\mathrm{C}_{3} \mathrm{CO}_{3}$ & $\mathbf{s}$ & $\mathbf{P}$ & $\mathrm{H}_{3} \mathrm{O} \mathrm{I}$ & it.lo & ash. \\
\hline & 6.46 & 12.56 & 10.49 & 5.93 & 0.40 & 0.74 & 1.32 & 15.01 & 0.69 & - & 2.57 & 1.49 & \\
\hline & 3.56 & 0.12 & 12.71 & 7.18 & 1.21 & 0.31 & $t_{r}$ & - & 0.58 & - & 0.65 & 74.15 & \\
\hline & 1.68 & $t r$ & 31.60 & 18.91 & $\mathbf{4 1 . 3 7}$ & 2.13 & 1.72 & - & 1.86 & $\ldots$ & - & - & \\
\hline
\end{tabular}

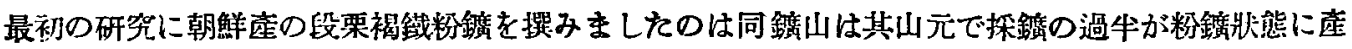

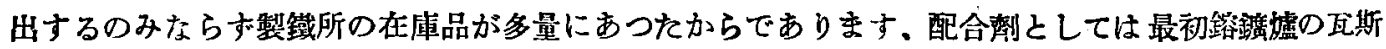
灰を使用し次に下等粉督炭を混用しました，爐況により各た $5 \%$ ％10\%を使用しよく段栗粉鈸に混合

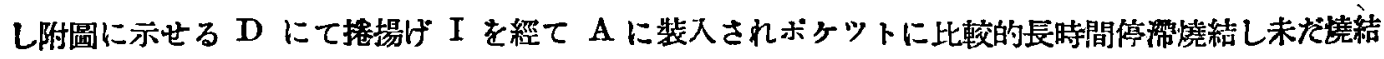
せさる粉狀のものはボケツト內の燒結物と爐壁の間に回轉輸送されて燒結物を押上げ從つて燒結物は

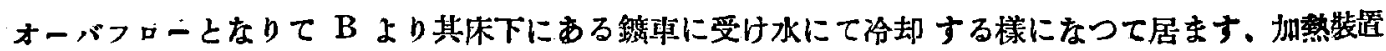




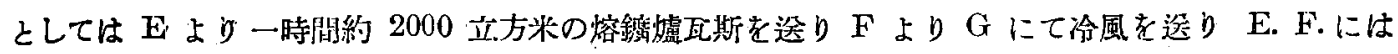

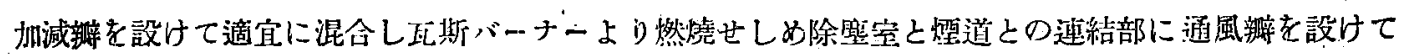

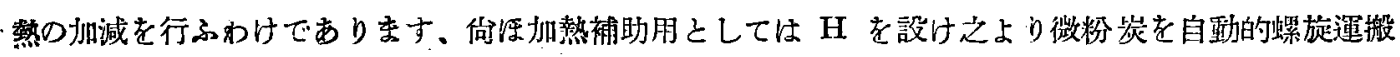
機にて F管に迩る样になつて居ますけれども目下溦粉炭を有せないので使用しては居ません，前述つ 通り裝入物の配合を加減し通風辫並に E.F.等の加減看を加減して出來るだけ熱を高める事に努力しま したけれどもどうしてる裝入物をポケツト內で燒結せしむる事が出來ませんでした。裝入物を少くす ると多少熱は上ります其で裝入を殆んど中止する位にして熱を上げますとAの小徑部即ちポケツトの

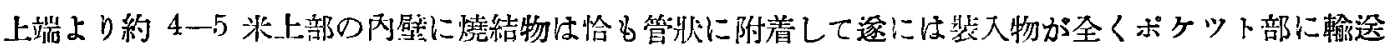

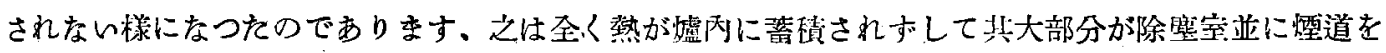

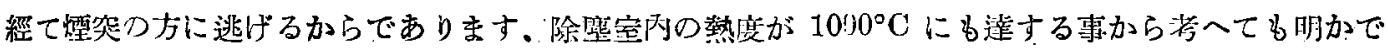
あります、通風辦等を如何に加減しましても此缺些を防ぐ事否緩和する事さへ困難でありましたから 種に研究しまして逐に爐先に或る裝置を設け、爐口よりは裝入物中の粉骸を完全に然燒せししる䍃め に別に過剩の椧風を邆入する装置を設けました所がポケツト內の熱は急激に上开し菲入量さへ少なく すれば僅かに 2-3\%の粉駭を加へてる殆んど鎔解狀態に燒絬せしむる事が出柬る樣になりました。 其で蓺の上昇には成功したわけですが一方には重大なる困難に遭遇したのでまります。バーナーの研 突により爐內に附着する管彇の燒結物を漸次輸狀堤の状態に變ぜしめ逐に附國に示す通りポケットの

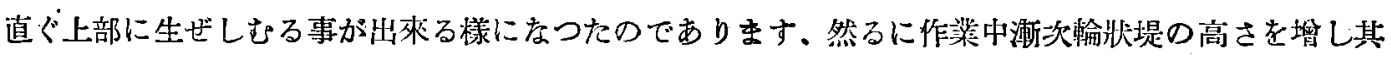
表面は急に還元されて海綃鐡となり d. の上部に第二のポケツトを生じ本來のポヶツト部には裝入物

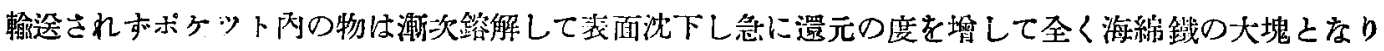

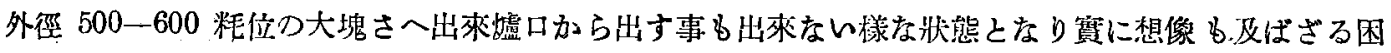
難に遭遇したのであります、褐鐵鈸粉は其燒結に最も必要なるネバリ即ち私は之を sticky length と 名づけて居ますが此 length が非常に短かく熱を下げると燒絬せず其かと云つて少し熱を上げると爱 に鉻解しまして恰も穊鐵の如を路解狀態を呈します、其で例人燒結物を鎔解狀態にして出しましても

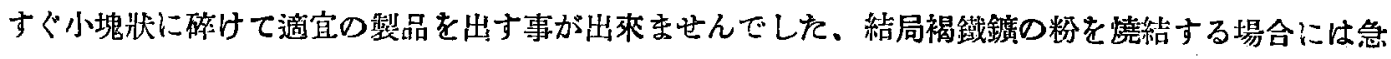
激な還元を防ぎ sticky length を適當ならしむる何等かの方法が必要である事を發見したかりであり

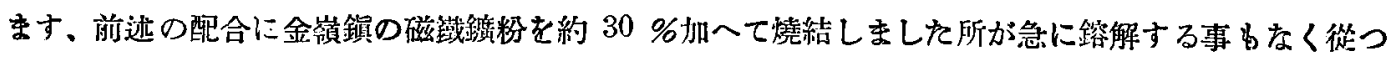
て sticky length b稍や良くなつて可なりの製品を出す事が出來る樣になりました、然るに倘涂榆状

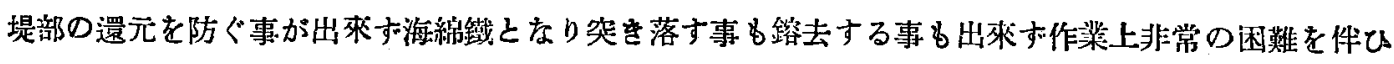
ますので配合劑として石灰石白零石等を加へて試驗しましたけれども燒結物は水にて冷却する際風化

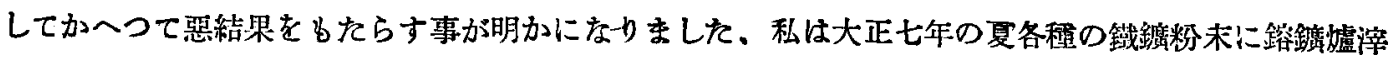

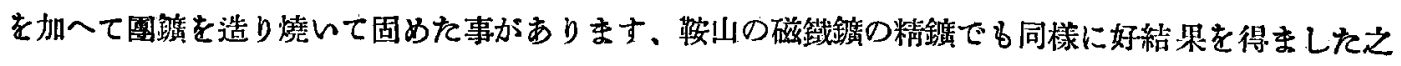

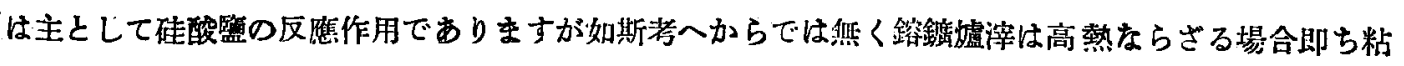


質の狀態では自身の還元は勿論之と混合する粉鑛の還元をる防ぐ事が出柬加ふるに・ $1000^{\circ} \mathrm{C}$ 位から既

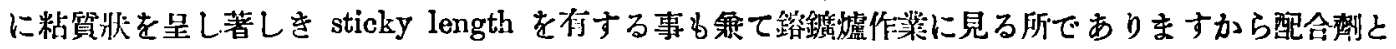

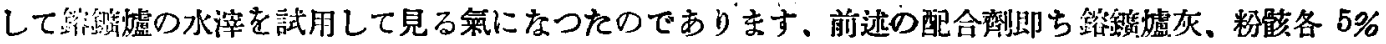
の外に向ほ水滓 $5 \%$ を扣へて陚驗しました所が桠跃堤部の還元を防ぐ事が出來 sticky length も理

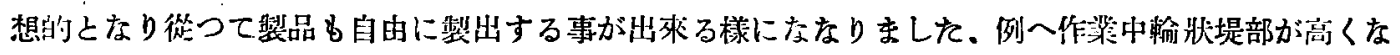

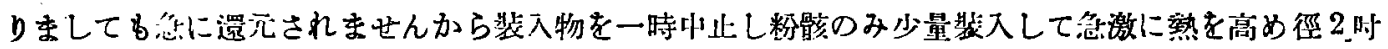

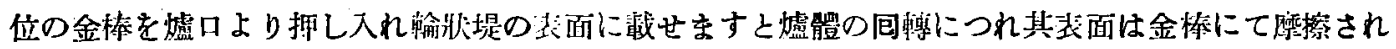

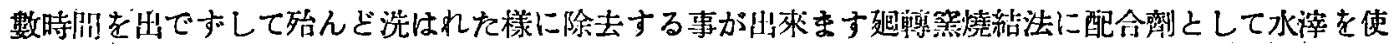

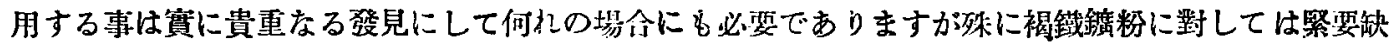

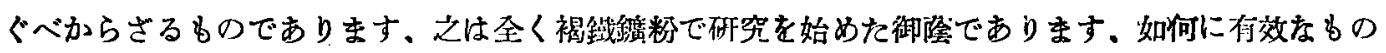

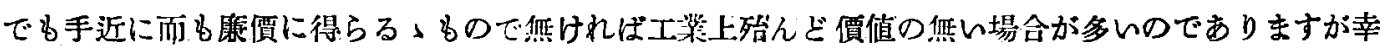

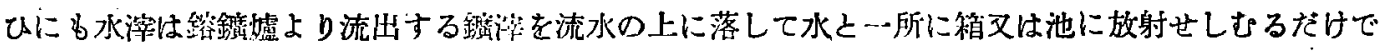

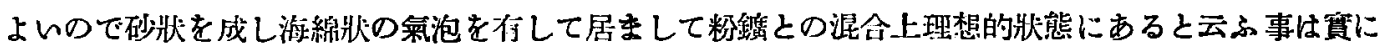

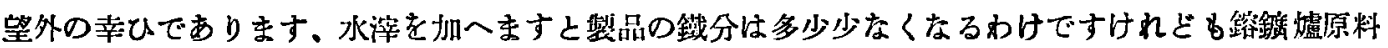
としてはかっつて有效であります。

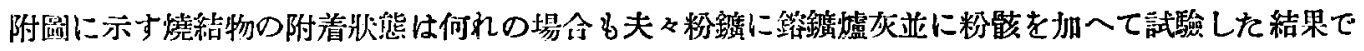
あります、今迄の研究によりまして附卧に示すが如く輪狀堤の譃臂に附着する部分即ち其 lengthに

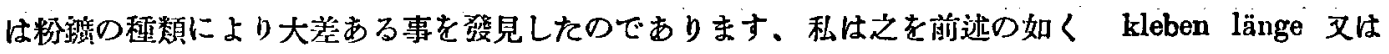
sticky. length と名つけけて居ます此 sticky length は還元の困難な粉銰症ど長いものである事を發見

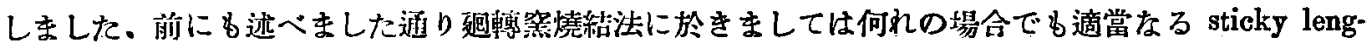
th が必要でありまして sticky length の加減は全く水䐠の混合量によりて成し得る事を發見したわ

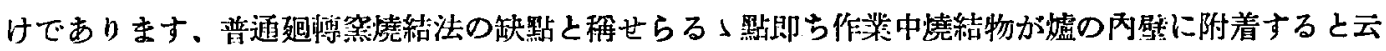

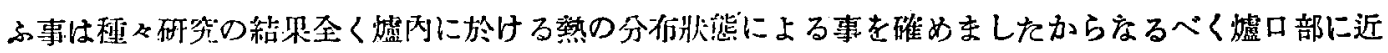

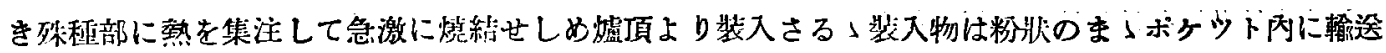

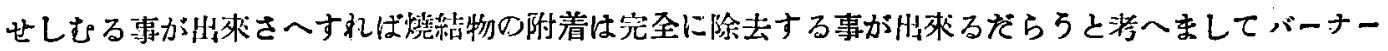
の研究に全力を盡したかけであります、大正十四年二月初句前述の将へを基礎としてバーナーを改造

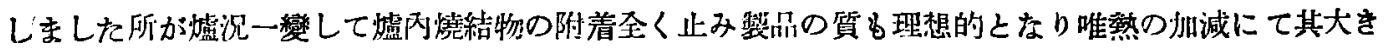

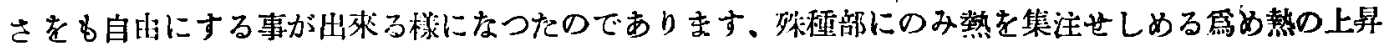

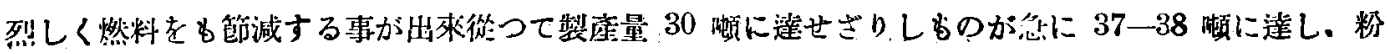

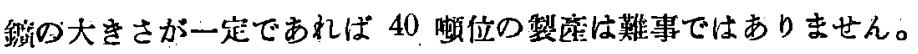

附劇に示す如くポケットより爐口に至る小亜部にも爐沉により多少の附着物を生する事があります

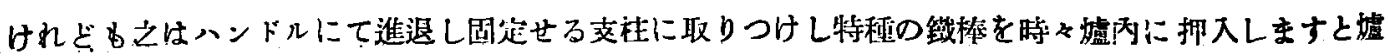




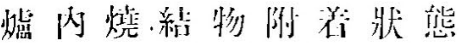

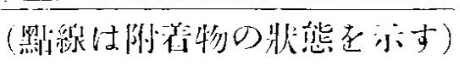

是度 $\mathrm{m} . \mathrm{m}$.

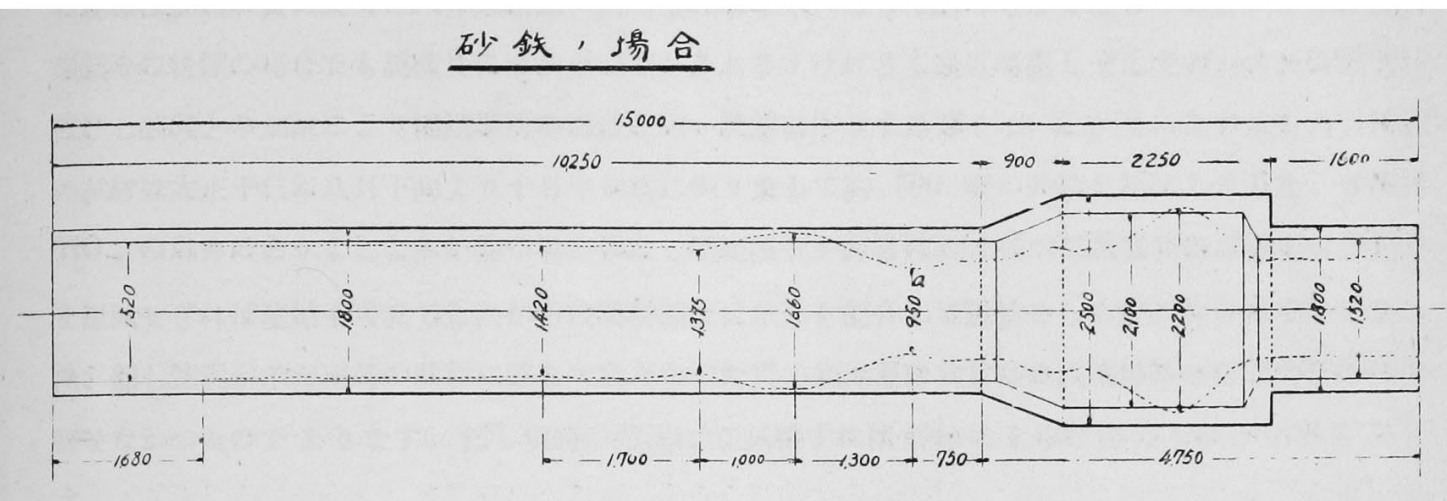

金、嶺鎮磁鉃鉱粉，場合

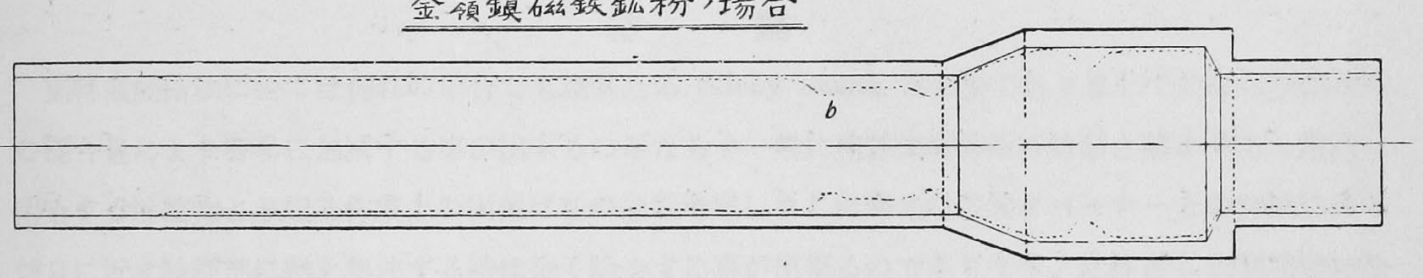

硫酸滓・場合
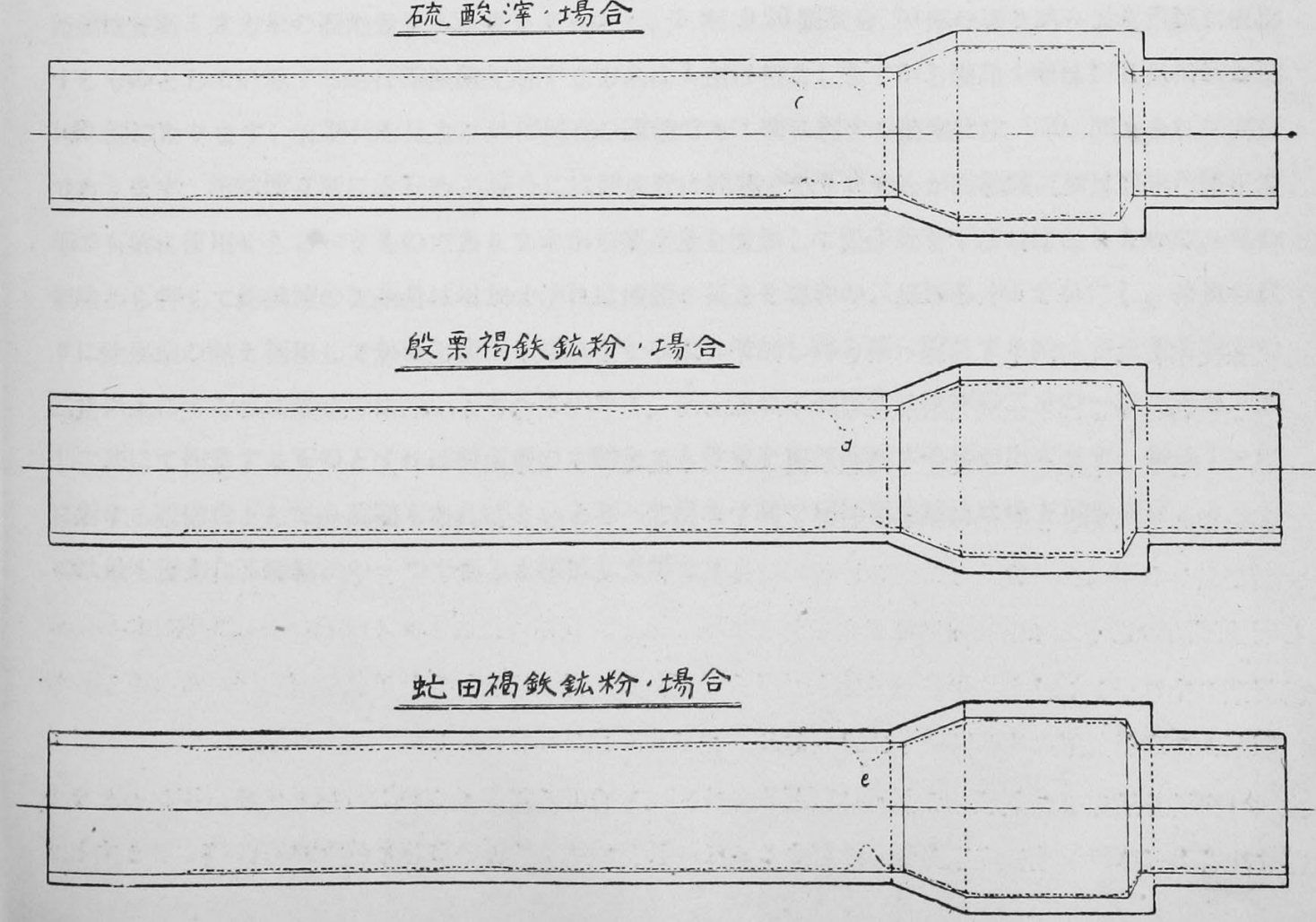


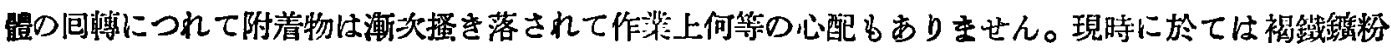
の燒結は製品の質に於ても又作菜狀熊に於ても理想の域に達して居るものと思つて居ます、硫酸滓金

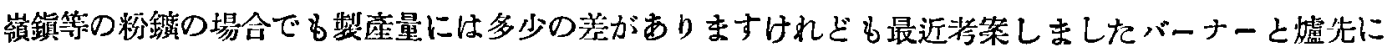

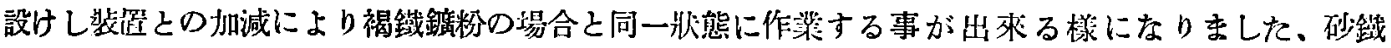

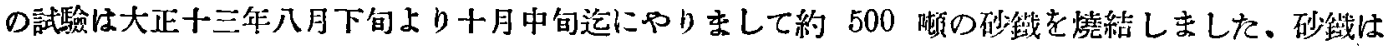

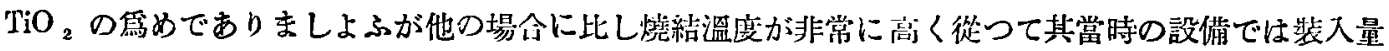
を激減せざれば燒結不可能でしたから段栗粉䥀道に水滓を配合して燒結せしめ製品約 800 瀬を得まし

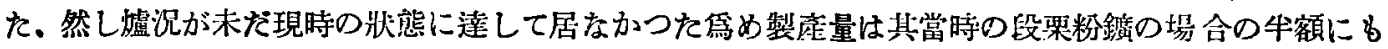
達せなかつたのであります、然し現時の爐況にて試驗すれば好絬果索舉げ得るものと信じて居ま す。

結 論

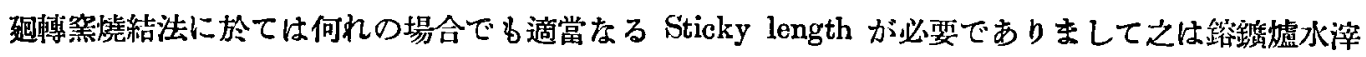
の混合量により容易に如減する事が出來るのみならず一般に趣㯖窒燒結法の缺點と稱せらる」爐內に

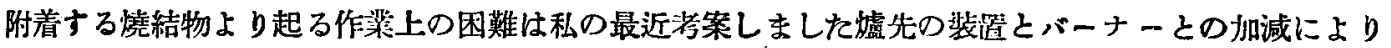
爐口に近を特種部に熱を集注する時は全く除去する事が出來るのであります之は實に迴轉䈍燒結法

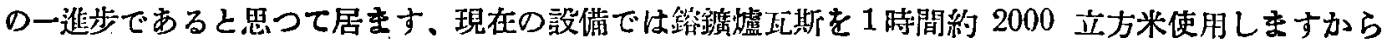

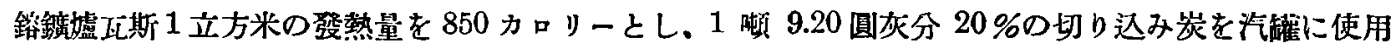

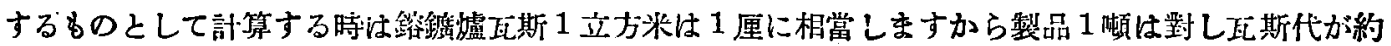

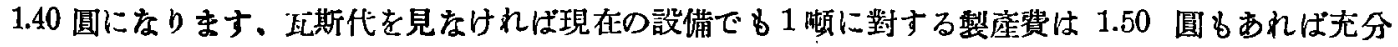

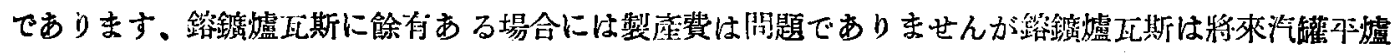
等で有效に使用せらるべをるのでありますから製音量を增加して製產費を下げねばなりません，私の

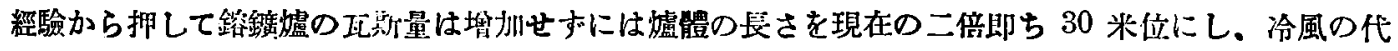
りに除案宣の熱を利用して熱風を使用し途風量を自由に增加し得る樣に設計する時は製意量を現在の

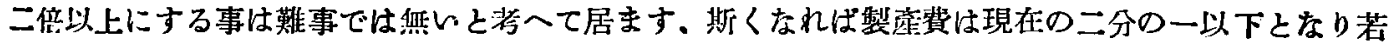

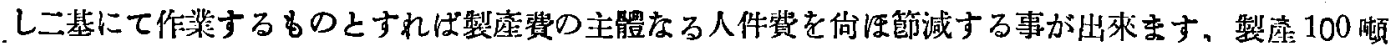

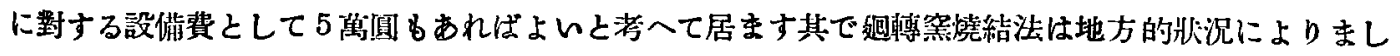
て恃最も㗄秀なる燒結㳂の一つであると確信して居ます。 